\title{
Correction to: Cost-effectiveness of rapid
} diagnostic tests, compared to microscopic tests, for the diagnosis and treatment of gestational malaria in Colombia from an institutional perspective

\author{
Deisy Cristina Restrepo-Posada ${ }^{1}$, Jaime Carmona-Fonseca ${ }^{2}$ and Jaiberth Antonio Cardona-Arias ${ }^{3^{*}}$
}

\section{Correction to: Malar J (2020) 19:400}

https://doi.org/10.1186/s12936-020-03472-6

Following publication of the original article [1], the authors reported that the following grant details had been omitted from the Funding declaration of their article: 'Grant support Project 111577757447. Contract 755-2017./Colciencias'.

The published article has now been corrected to include these details in the Funding declaration.

The authors apologize for any inconvenience caused.

\section{Reference}

1. Restrepo-Posada DC, Carmona-Fonseca J, Cardona-Arias JA. Costeffectiveness of rapid diagnostic tests, compared to microscopic tests, for the diagnosis and treatment of gestational malaria in Colombia from an institutional perspective. Malar J. 2020;19:400. https://doi.org/10.1186/ s12936-020-03472-6.

\section{Publisher's Note}

Springer Nature remains neutral with regard to jurisdictional claims in published maps and institutional affiliations.

\section{Author details}

${ }^{1}$ University of Antioquia, Medellin, Colombia. ${ }^{2}$ Department of Medicine, University of Antioquia, Medellin, Colombia. ${ }^{3}$ School of Microbiology, University of Antioquia, Calle 70 Number 52-51, Block 5, ofce 103, Medellin, Colombia.

Published online: 20 January 2021

The original article can be found online at https://doi.org/10.1186/s1293 6-020-03472-6.

*Correspondence: jaiberth.cardona@udea.edu.co

${ }^{3}$ School of Microbiology, University of Antioquia, Calle 70 Number 52-51, Block 5, ofce 103, Medellin, Colombia

Full list of author information is available at the end of the article

(c) The Author(s) 2020. This article is licensed under a Creative Commons Attribution 4.0 International License, which permits use, sharing, adaptation, distribution and reproduction in any medium or format, as long as you give appropriate credit to the original author(s) and the source, provide a link to the Creative Commons licence, and indicate if changes were made. The images or other third party material in this article are included in the article's Creative Commons licence, unless indicated otherwise in a credit line to the material. If material is not included in the article's Creative Commons licence and your intended use is not permitted by statutory regulation or exceeds the permitted use, you will need to obtain permission directly from the copyright holder. To view a copy of this licence, visit http://creativecommons.org/licenses/by/4.0/. The Creative Commons Public Domain Dedication waiver (http://creativecommons.org/publicdomain/zero/1.0/) applies to the data made available in this article, unless otherwise stated in a credit line to the data. 